\title{
Biological test of compost made of rabbit faeces and the addition of banana peels on the vegetative growth of Morus alba and Arachis pintoi
}

\author{
Nur Cholis ${ }^{1,2, *}$ and Ita Wahju Nursita ${ }^{1,2}$ \\ ${ }^{1}$ Department of Animal Production, Faculty of Animal Science, Universitas Brawijaya, Malang \\ 65145, Indonesia \\ ${ }^{2}$ Research Group of Animal Waste and Compost Technology, Faculty of Animal Science, \\ Universitas Brawijaya, Malang 65145, Indonesia
}

\begin{abstract}
The purpose of this research was to determine vegetative growth performance of Morus alba and Arachis pintoi with different percentages of compost mixture (rabbit feces and kepok banana (Musa paradisiaca Linn) peels) and soil as media. The materials used was 72 Morus alba stacks, rabbit faeces, kepok banana peels, and Azotobacter culture as decomposer. This research was conducted by Completely Randomized Design with 4 treatments and 6 replications. The treatments were $\mathrm{T}_{0}\left(100 \%\right.$ soil), $\mathrm{T}_{1}$ ( $20 \%$ of compost and $80 \%$ of soil), $\mathrm{T}_{2}(40 \%$ of compost and $60 \%$ of soil), and $\mathrm{T}_{3}(60 \%$ of compost and $40 \%$ of soil). The data was analysed using analysis of variance, followed by Duncan's Multiple Range Test (DMRT) if the results are significantly different. The treatment gave higher leaves number, roots weight, and roots length $(\mathrm{P}<0.05)$ in Morus alba. Same also on plant length, branches number and wet weight $(\mathrm{P}<0.05)$ of Arachis pintoi. The conclusion of this research is that the application of organic compost based on rabbit manure and banana peel with Azotobacter microbial culture decomposer can improve the growth performance of Morus alba and Arachis pintoi. The best level was $\mathrm{T}_{1}$ with $20 \%$ of compost and $80 \%$ of soil.
\end{abstract}

\section{Introduction}

The number of rabbits in East Java Province in 2019 reached 370,107 heads. This figure has increased by $1.56 \%$ from 2018 which could reach 367,983 heads. This makes East Java Province ranked 2nd with the largest number of rabbit populations in Indonesia [1]. Public awareness with a healthy lifestyle has made rabbit meat popular because of high protein but low cholesterol meat. The protein and fat content of rabbit meat is still better than chicken meat $(20.8 \%$ vs $18.2 \%)$. Rabbit fat content is $10.2 \%$ while chicken fat is $25 \%$. This makes rabbit farmers compete to increase rabbit meat production. The increase in the number of

\footnotetext{
*Corresponding author: ncholis@ub.ac.id
} 
rabbits was followed by an increase in the feces produced. Adult rabbits weighing $1 \mathrm{~kg}$ produce 28 grams of feces per day [2].

Rabbit feces contain better nitrogen, phosphorus, and potassium than other livestock such as cattle, sheep, buffalo, horses, and chickens [3]. Tumimbang et al. [4] stated that rabbit manure has a total $\mathrm{N}$ value of $2 \%, \mathrm{P}_{2} \mathrm{O}_{5} 1.5 \%, \mathrm{~K}_{2} \mathrm{O}<1 \%$, and organic $\mathrm{C}-10 \%$.

Bananas are one of the most abundant fruits, especially in the tropics. Based on data by Abdullah et al [5], the Kepok Tanjung banana has a yield potential of 20-30 tons/ha/year. Banana is one of the fruits that people are interested in because it has good benefits, especially for health. However, the consumption of bananas will leave waste in the form of banana peels. The weight of the banana peel waste is quite a lot, which is about $1 / 3$ of an unpeeled banana [6].

The selection of Kepok (Musa paradisiaca Linn) banana peels was because the higher nitrogen content than that of Ambon bananas and Raja bananas. According to Sriharti and Takiyah [7] nitrogen in Kepok banana peels is $1.34 \%$ while Ambon bananas $0.21 \%$ and Raja bananas $0.07 \%$. Rabbit faeces and Kepok banana peels are wastes that still contain good nutrients for plants after going through the composting process.

Pintoi beans (Arachis pintoi) are one of the most palatable food crops for livestock, have high nutritional value and have several functions, namely as feed for both ruminants and non-ruminants, increasing soil fertility and preventing erosion [8]. The nutritional content of Arachis pintoi is protein 17.06\%; crude fibre $17.96 \%$; $3.54 \%$ fat; BETN $53.43 \%$ and ash $8.01 \%$.

Mulberry (Morus alba) is an animal feed plant that is generally used as feed for silkworms. Morus alba has the characteristics of pinnate leaves with jagged edges. The development of mulberry planting patterns needs to be improved because mulberry leaves are the only food for silkworms to be able to produce cocoons which will become silk fibers. However, big and small ruminants also like mulberry leaves.

This study aims to determine the ability of the composted media from rabbit faces with the addition of Kepok banana peel waste in the vegetative growth of Morus alba and Arachis pintoi plants, and to determine the best proportion in their use.

\section{Materials and methods}

The materials used in this study were rabbit faeces Kepok banana peel waste ( $M$. paradisiaca Linn), Azotobacter culture decomposer, river sediment soil, Morus alba and Arachis pintoi plants.

About $97.2 \mathrm{~kg}$ of rabbit faeces were obtained from rabbit breeders in Arjosari. Kepok banana peel waste as much as $32.4 \mathrm{~kg}$ was obtained from the Kepok banana chips factory which is located at Jln. Mentaraman Gang VII Talok Turen Malang 65175. Banana peel waste which had previously been dried under the sun and then chopped. Microbial culture was purchased online and used as much as $525 \mathrm{~mL}$.

The composting equipment consists of a large straw chopper, $150 \mathrm{~L}$ plastic bucket, portable hanging scales $0-10 \mathrm{~kg} / 5 \mathrm{~g}, 10-50 \mathrm{~kg} / 10 \mathrm{~g}$, litmus $\mathrm{pH}$ indicator on a scale of $1-14$, trash bag plastic sacks, mercury thermometer. Planting media equipment consists of polybags measuring $35 \mathrm{~cm}$ x $30 \mathrm{~cm}$, measuring 0-2 meters, digital scales 0-5 kg scale, folio paper and scissors

The equipment for making the decomposer solution consists of a $26 \mathrm{~L}$ plastic bucket, 1 $\mathrm{L}$ measuring cup and a stirrer. The decomposer solution was prepared by mixing $525 \mathrm{~mL}$ of Azotobacter culture (trademark MA110) with $2 \%$ sugar and $26.25 \mathrm{~L}$ of water.

Mulberry seedlings are stem cuttings with a diameter of $1-1.5 \mathrm{~cm}$ and a minimum of 5 buds and have been grown for 1 month before being planted in the treatment planting medium. Arachis pintoi plants with an age of approximately 30 days were uniformed by 
trimming so that they had a length of around $8 \mathrm{~cm}$. Compost composition is $75 \%$ rabbit feces and 25\% banana Kepok waste [9].

The study was conducted using a Completely Randomized Design/CRD experiment consisting of 4 treatments and 6 replications. The treatments were $\mathrm{T}_{0}(100 \%$ soil $), \mathrm{T}_{1}(20 \%$ compost $+80 \%$ soil $), \mathrm{T}_{2}$ (40\% compost $+60 \%$ soil $)$, and $\mathrm{T}_{3}(60 \%$ compost $+40 \%$ soil $)$. The study began with composting rabbit faces and Kepok banana peel waste for 8 days with the help of the Azotobacter decomposer. The composted fertilizer was then applied to the Morus alba plant to observe its vegetative growth for 29 days. Observations were made on the leaves number, root weight, and plant root length.

The composted fertilizer was then applied to Arachis pintoi plants to observe their vegetative growth for 29 days. Observations were made on plant height, branches number, and plant fresh weight. Planting the tested plant seeds on the planting media begins with opening the polybag of plant seeds using a sharp knife so that the lumps of soil in the polybag are not damaged. After the seeds are placed in the holes in the planting medium, the surrounding soil is loosened and compacted. Plant seeds are selected that are uniform.

The planting environment is shaded using para-net or black nets to provide shade for plants of about $40 \%$. Watering is done twice a day, giving water as much as $250 \mathrm{ml} /$ polybag/day. Watering is done 1 week after planting, if there are plants that die, they are replaced with new plants with the same age and height as before, the goal is that the plants can grow uniformly. Weeding is done when there are weeds that interfere with plants. Weeding is done once a week or according to weed development. The data obtained were then analysed by Analysis of Variance and continued with Duncan's Multiple Distance Test to determine the best treatment.

\section{Results and discussion}

\subsection{Physical properties of compost}

Composting was carried out for 8 days. Table 1 below informs the results of the color, texture, and odor of the compost during the study. In general, the mature compost has physical characteristics such as blackish brown color and smells close to the smell of earth. This is because the material it contains already resembles soil material.

Table 1. Compost color, texture, and smell during the study

\begin{tabular}{|c|c|c|c|}
\hline Days to & Color & Smell & Texture \\
\hline 1. & Light brown & Banana peel & Mushy \\
\hline 2. & Light brown & Sour and banana peel & Mushy \\
\hline 3. & Light brown & Sour and banana peel & Mushy \\
\hline 4. & Dark brown & Sour and banana peel & Mushy \\
\hline 5. & Dark brown & Sour and banana peel & Mushy \\
\hline 6. & Dark brown & Sour and banana peel & Mushy \\
\hline 7. & Dark brown & Smell of earth & Mushy \\
\hline 8. & Dark brown & Smell of earth & Crumb \\
\hline
\end{tabular}


Blackish brown color formed by the influence of stable organic matter. The final form of composting does not resemble the original form because it has been destroyed due to natural decomposition by microorganisms that live in the compost. The texture at the beginning of composting tends to be soft until the last day the compost texture when you hold it no longer sticks to your hands (crumbs). This is in accordance with Ayunin et al. [10] that the mature compost is blackish brown in color, smells like soil and has a crumb texture. The size of the compost pile becomes smaller than at the beginning of composting which indicates that there is degradation activity by various bacteria in the compost [11].

\subsubsection{Compost temperature}

Figure 1 shows the development of the compost temperature during the process. On the first day of composting (October 22,2020 ) the temperature was $28^{\circ} \mathrm{C}$, on the second day the temperature rose to $30.67^{\circ} \mathrm{C}$, then on the third day to day 8 (October 8,2020 ) the temperature gradually dropped slowly.

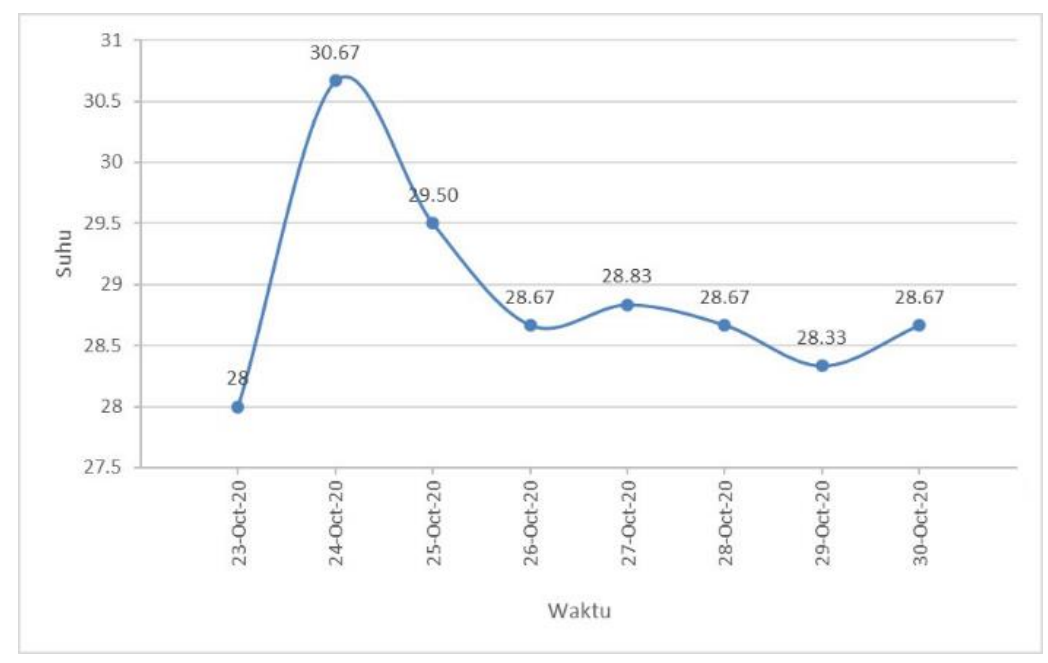

Fig. 1. Graph of temperature development compost

The increase in temperature occurs because the decomposition activity carried out by bacteria will produce heat and the temperature will rise until it reaches the maximum temperature, after that the temperature will decrease like the initial temperature [12]. It is supported by Irawan [13] that in the early stages of composting there are mesophilic bacteria. These bacteria live at a temperature of $10-40^{\circ} \mathrm{C}$. The decrease in temperature during the composting process is in line with the decrease in the number of bacteria due to reduced nutrients and the compost returns to its initial temperature [14]. Azotobacter is a mesophilic bacterium that can live at a temperature of $20-30^{\circ} \mathrm{C}$.

\subsubsection{Compost $\mathrm{pH}$}

The results of the observation of $\mathrm{pH}$ during the composting process can be seen in Figure 2 . During the observation of fluctuating $\mathrm{pH}$, the first day the $\mathrm{pH}$ showed acid, then on the second day the $\mathrm{pH}$ began to rise to a peak point on the third day of 7.5 , then gradually decreased to 6 and increased until the $\mathrm{pH}$ neutral. According to Supadma and Arthagama [15] at the beginning of composting, the $\mathrm{pH}$ tends to be acidic due to the formation of organic acids, then the $\mathrm{pH}$ increases due to protein decomposition and the release of 
ammonia. The rise and fall of $\mathrm{pH}$ is also a sign of bacterial activity in decomposing organic matter [16].

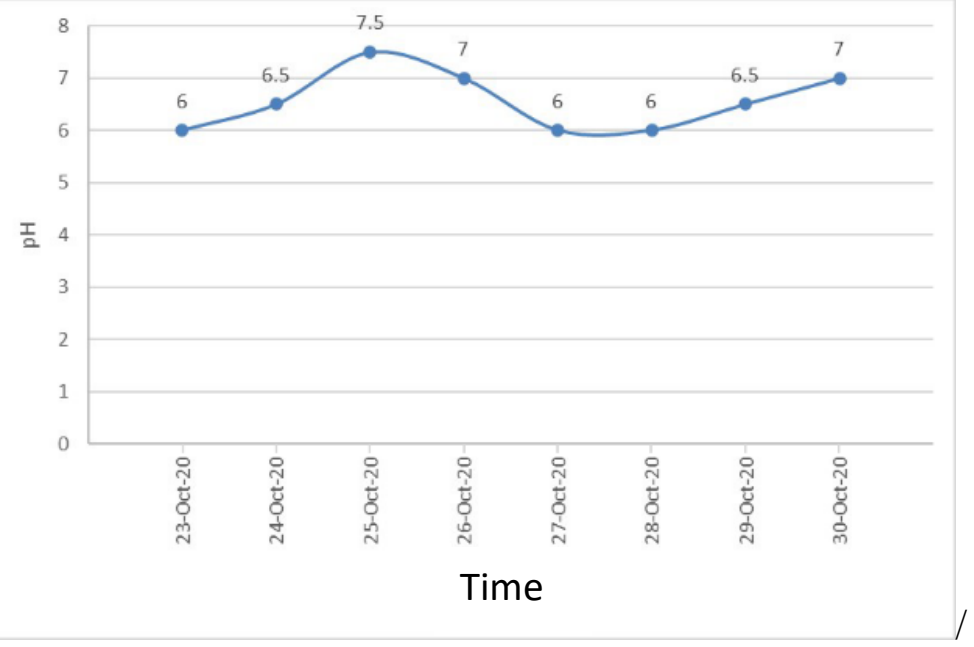

Fig. 2. Compost $\mathrm{pH}$ development

\subsection{Compost nutrient content}

The nutrient content and chemical properties of the compost are known after the samples were tested in the UPT Lab for the Development of Agribusiness for Food Crops and Horticulture in Bedali - Lawang as shown in Table 2.

$\mathrm{T}_{1}$ has the highest water content, namely $21 \%$, followed by $\mathrm{T}_{2} 16 \%$, then $\mathrm{T}_{3} 14 \%$ and pure compost $17 \%$. This happens because of the influence of plant soils that have high water content.

Table 2. Compost nutrient content

\begin{tabular}{|c|c|c|c|c|c|c|}
\hline Element & $\mathrm{SNI}^{*}$ & Compost & $\mathrm{T}_{0}$ & $\mathrm{~T}_{1}$ & $\mathrm{~T}_{2}$ & $\mathrm{~T}_{3}$ \\
\hline$\%$ Water & Max 50 & 17 & 21 & 21 & 16 & 14 \\
\hline $\mathrm{C}-$ org & 9,8 & 24.6 & 1.5 & 9 & 9 & 6 \\
\hline $\mathrm{C} / \mathrm{N}$ & Min $10 \%$ & 23.21 & - & 10 & 10 & $7-79$ \\
\hline$\% \mathrm{~N}$ & Min 0.4 & 1.06 & - & 0.9 & 0.9 & 0.77 \\
\hline$\% \mathrm{P}_{2} \mathrm{O}_{5}$ & 0.1 & 1.05 & - & 0.72 & 0.8 & 0.55 \\
\hline$\% \mathrm{~K}_{2} \mathrm{O}$ & 0.2 & 3.22 & - & 0.95 & 1.5 & 2.05 \\
\hline $\mathrm{OM}$ & $27-58$ & 42.39 & 2.6 & 15.5 & 15.5 & 10.3 \\
\hline
\end{tabular}

According to Mayasari et al. [17], the water content of the soil is $43.55 \%$. Each soil has a different water content depending on the condition of the plant soil. MA-11 is composed of Rhizobium sp. bacteria combined with bacteria taken from the rumen of cows, namely cellulolytic bacteria, proteolytic bacteria, and amylolytic bacteria which are tasked with 
breaking down cellulose so that it is easily consumed by Rhizobium sp. bacteria which are active in binding free nitrogen.

Analysis of $\mathrm{P}$ content in compost has exceeded SNI 19-7030-2004, compost only $\left(\mathrm{T}_{0}\right)$ $1.05 ; \mathrm{T}_{1} 0.72 ; \mathrm{T}_{2} 0.8$, and $\mathrm{T}_{3} 0.55$ where the standard is 0.1 . Ratna et al. [18] said that in the composting process some phosphorus is absorbed by microorganisms to form proteins in the body. The more microorganisms, the faster the compost will ripen.

$\mathrm{K}$ content in compost is quite high, pure compost only $\left(\mathrm{T}_{0}\right)$ has a level of 3.22 , far above SNI 19-7030-2004 with a minimum $\mathrm{K}$ content of only 0.2 . This is influenced by the addition of Kepok banana peels in the composted material. Akbari et al. [19] said that based on laboratory tests at the University of North Sumatra, it was known that the $\mathrm{K}_{2} \mathrm{O}$ element content in the kepok banana peel was $1.478 \%$.

\subsection{Compost biological test}

\subsubsection{Morus alba}

Table 3 presents the results of the biological test of rabbit faeces compost with the addition of Kepok banana peels on Morus alba vegetative growth.

Table 3. Leaves number (sheets), root weight (g), and root length (cm) of Morus alba

\begin{tabular}{|c|c|c|c|c|}
\hline Variable & $\mathrm{T}_{0}$ & $\mathrm{~T}_{1}$ & $\mathrm{~T}_{2}$ & $\mathrm{~T}_{3}$ \\
\hline Leaves number & $13.7 \pm 1.25^{\mathrm{a}}$ & $27.7 \pm 5.01^{\mathrm{bc}}$ & $24.5 \pm 8.78^{\mathrm{bc}}$ & $19.7 \pm 9.07^{\mathrm{ab}}$ \\
\hline Root weight & $4.3 \pm 1.25^{\mathrm{a}}$ & $16.0 \pm 3.37^{\mathrm{c}}$ & $12.9 \pm 2.33^{\mathrm{bc}}$ & $10.3 \pm 4.36^{\mathrm{b}}$ \\
\hline Root length & $9.9 \pm 1.53^{\mathrm{a}}$ & $23.1 \pm 3.49^{\mathrm{bc}}$ & $18.6 \pm 7.39^{\mathrm{bc}}$ & $14.2 \pm 1.98^{\mathrm{ab}}$ \\
\hline
\end{tabular}

Leaf growth indicates the presence of cell metabolism in plants. The results showed that the $\mathrm{T}_{1}(20 \%$ compost $+80 \%$ soil $)$ gave the highest average leaves number $(\mathrm{P}<0.05)$ compared to other treatments. Based on Duncan's multiple-distance follow-up test, it was found that the $T_{1}$ and $T_{2}$ treatments gave the highest effect and did not differ from the $T_{3}$ treatment compost.

Leaf growth is affected by some factors, including the level of nitrogen absorbed by plant roots. Adi et al. [20] that nitrogen is an important element for plants in vegetative growth. Nitrogen plays a role in stimulating overall plant growth, especially in stems, branches, and leaves and the formation of green leaves (chlorophyll). Furthermore, Augustien and Suhardjono [21] explained that leaf formation by plants is strongly influenced by the availability of nitrogen and phosphorus nutrients in the medium and those available to plants. These two elements play a role in the formation of new cells and are the main components of organic compounds in plants such as amino acids, nucleic acids, chlorophyll, ADP, and ATP.

The application of treated compost fertilizer at the level of $20 \%\left(\mathrm{~T}_{1}\right)$ was considered to have the best effect on the growth of the leaves number of the mulberry plant (Morus alba). The nitrogen $(\mathrm{N})$ content in the P1 treatment fertilizer was $0.9 \%$. Nitrogen levels in compost can help plants in the formation of leaves. Nitrogen makes plant parts green because it contains chlorophyll which plays a role in photosynthesis. This element is also useful for accelerating plant growth in height, increasing the tillers number, influencing leaf width and length, and making them large, increasing protein and fat levels of plants.

In addition to nitrogen, phosphorus (P) also plays a role in plant growth, including leaf growth. In Liferdi's research [22] stated that phosphorus had a significant effect on plant 
height, branch length, branches number, and leaves number. The leaves number increased as the phosphorus dose increased. This is because phosphate is needed by plants for the formation of cells in plant tissues.

In addition, the element potassium $(\mathrm{K})$ also has a role in the growth and leaves number. Potassium can maintain cell turgor pressure and water content in plants, increase plant resistance to disease and drought, and improve yields and crop quality [23]. This is in accordance with Uke et al. [24] who stated that the addition of potassium has a very significant effect in increasing the leaves number. Potassium is also a source of strength for plants in the face of drought and disease. Plants that are deficient in potassium have symptoms of shrivelled and dry leaves.

Based on the analysis of variance that has been carried out, it is known that giving compost treatment $\mathrm{T}_{1}(20 \%$ compost $+80 \%$ soil $)$ gave the highest average root weight compared to other treatments $(\mathrm{P}<0.01)$. Furthermore, with Duncan's follow-up test, it can be concluded that the treatment of $\mathrm{T}_{1}$ compost gave the highest root weight and did not differ from that of the $\mathrm{T}_{2}$ treatment compost.

Root growth is an important factor in plant growth. Roots play a role in absorbing elements in the planting medium so that plants can use them for growth. Sutarta et al. [25] explain that in the mechanism of nutrient absorption by plants, roots are organs that function in absorbing nutrients from the soil, so roots are an important factor in determining plant productivity. Root growth potential is necessary.

The mulberry plant (Morus alba) has a taproot system so that its growth requires phosphorus to strengthen its roots. Phosphorus content in compost has a very significant effect on the average weight of plant roots. This is in line with Adi et al. [20] which states that the element phosphorus (P) helps in root growth and strengthens roots. Phosphorus is needed in large quantities so that it is a macro element needed by plants, especially in the vegetative phase of plants. Phosphorus plays a role in increasing root development and as a source of energy by forming ATP [26].

Other elements such as nitrogen and potassium also contribute to the root weight of Morus alba. In the research of Sunarto et al. [27], it was stated that the administration of $\mathrm{KNO}_{3}$ influenced one of the variables in increasing root weight. However, it is inversely proportional to the increase in nitrogen which reduces root weight. So that the element of potassium also contributes to increasing the weight of plant roots because potassium functions in improving the root system [28].

Roots are an important part of plants because they have a role in finding and absorbing nutrients and nutrients contained in the soil to be used during plant growth. So that the soil used as a planting medium must contain the nutrients that plants need. One of the ways to increase nutrients and soil quality is the addition of organic fertilizer or compost. The ability of plant cuttings to form roots is influenced by natural growth regulators in plants (phytohormones), as well as growth regulators given exogenously, to produce a good root system [29].

Root growth is in line with the leaves number that grow. In the leaves, photosynthesis occurs which will produce a certain amount of energy to carry outgrowth for plants, one of which is root growth. In this process, potassium $(\mathrm{K})$ is needed which plays a role in the process of photosynthesis and metabolism as well as nutrient transport in plants. Potassium contained in pure compost because of research is $3.22 \%$. This value is in accordance with the SNI Compost standard which states that the potassium content in compost is at least $0.2 \%$. Potassium levels in $\mathrm{T}_{1}, \mathrm{~T}_{2}$, and $\mathrm{T}_{3}$ treated compost also showed values that were in accordance with SNI standards with values of $0.95 \%, 1.49 \%$, and $2.05 \%$, respectively. Satriawi et al. [30] explained that potassium plays a role in the movement of photosynthate out of the leaves to the roots and can increase the supply of energy for root growth. Therefore, the more nutrients that are absorbed by the plant, the more photosynthate will 
accumulate in the roots for growth [31]. Plants that have an adequate supply of potassium, the photosynthetic and metabolic processes will run well [20].

\subsubsection{Arachis pintoi}

Table 4 presents the results of the biological test of rabbit faeces compost with the addition of Kepok banana peels on Arachis pintoi.

Table 4. Plant length (cm), root weight (g), and fresh weight (g) of 58 days old Arachis pintoi

\begin{tabular}{|c|c|c|c|c|}
\hline Variable & $\mathrm{T}_{0}$ & $\mathrm{~T}_{1}$ & $\mathrm{~T}_{2}$ & $\mathrm{~T}_{3}$ \\
\hline Plant length & $14.6 \pm 0.96^{\mathrm{a}}$ & $19.11 \pm 2.51^{\mathrm{c}}$ & $17.9 \pm 3.20^{\mathrm{bc}}$ & $16.7 \pm 1.08^{\mathrm{ab}}$ \\
\hline Branches number & $12.2 \pm 3.3^{\mathrm{a}}$ & $19.8 \pm 5.98^{\mathrm{bc}}$ & $12.9 \pm 2.33^{\mathrm{bc}}$ & $14.6 \pm 2.30^{\mathrm{ab}}$ \\
\hline Fresh weight & $21.2 \pm 1.73^{\mathrm{a}}$ & $29.8 \pm 6.99^{\mathrm{c}}$ & $26.6 \pm 1.65^{\mathrm{bc}}$ & $26.6 \pm 1.65^{\mathrm{bc}}$ \\
\hline
\end{tabular}

Arachis pintoi plants do not grow upright but propagate above the soil surface. Measurement of plant length is more accurate for this close relative of the peanut plant (Arachis hypogea) than plant height. Some of the advantages of this plant are drought resistance, can grow on various types of soil or low soil fertility, low $\mathrm{pH}$, or aluminiumsaturated soil [32] and shade with an intensity of up to $50 \%$ [33].

In Table 4 above, the planting medium without the addition of rabbit faeces compost and Kepok banana peel $\left(\mathrm{T}_{0}\right)$ had the lowest plant length $(\mathrm{P}<0.05)$. Plant media with treatment received additional supply of N, P, K from rabbit faeces and kepok banana peels as can be seen in Table 2 regarding the nutrient content of compost. Duncan test results showed that $T_{1}$ plants gave a significant difference with $T_{3}$ and $T_{0}$ and did not differ from $\mathrm{T}_{2}$. Similarly, the effect of adding compost to the growing media on the branches number and fresh weight.

The branches number produced is due to the high levels of N, P, K elements found in rabbit faeces. According to R. Anwar and Djatmiko. [34] rabbit faeces contained 2.28\% nitrogen, $2.31 \% \mathrm{P}_{2} \mathrm{O}_{5}$ and $1.34 \% \mathrm{~K}_{2} \mathrm{O}$. Andri and Wawan [35] state that the increase in the branches number occurs due to the process of cell division and elongation as well as nutrients that can increase plant productivity, such as $\mathrm{N}, \mathrm{P}$ and $\mathrm{K}$ elements. Plant height growth is a physiological process in which cells divide.

According to Astutik et al [36] that potassium has an important role in the photosynthesis of protein and cellulose formation, in addition to strengthening plant stems and accelerating the growth of existing stems. One of the functions of nitrogen is to form chlorophyll which functions in the process of photosynthesis. The higher the nitrogen application, the amount of chlorophyll formed will increase.

The increase in the amount of chlorophyll has an impact on the rate of photosynthesis which also increases so that plant growth is faster and maximum. According to Koryati [37] the results of photosynthesis are used for the growth of plant organs, where the larger the plant organs formed, the more water content that can be bound by plants. In addition, the higher the plant height and leaf area, the higher the fresh weight of the plant. This is supported by Prasetya et al. [38] that the fresh weight of plants is influenced by plant height and leaf area, where the higher and larger the leaf area, the fresh weight of the plant will be higher. 


\section{Conclusion}

The application of organic compost based on rabbit manure and banana peel with Azotobacter microbial culture decomposer can improve the vegetative growth of Morus alba and Arachis pintoi. The best level was $\mathrm{T}_{1}$ with $20 \%$ of compost and $80 \%$ of soil.

\section{References}

1. Direktorat Jenderal Peternakan dan Kesehatan Hewan, Populasi Kelinci 2014-2019 (2018)

2. S. M. Sholihah and M. A. Wahyunigrum, Jurnal Ilmiah Respati Pertanian, 2, $650-658$ (2016)

3. M. Nurrohman, A. Suryanto, Karuniawan Puji W., Jurnal Produksi Tanaman, 2, 649657 (2015)

4. M. Tumimbang, Z. E. Tamod, W. Kumolontang, Eugenia, 22, 123-133 (2016)

5. M. A. Abdullah, J. Wardie and A. P. Berka, Journal Socio Economic Agricultural, 14, $48-56$ (2019)

6. I. S. Manis, I. Said, Jurnal Akademia Kim, 6, 219-226 (2017)

7. Sriharti and Takiyah, Prosiding Seminar Nasional Teknoin, 1, B72-B77 (2008)

8. N. G. K. Roni, N. N. Candraasih, M. Witariadi, N. W. Siti, Majalah Ilmiah Peternakan, 20, 29-32 (2017)

9. H. N. A. Kurniawan, S. Kumalaningsih, A. Febrianto, Buletin Peternakan, 1, 1-8 (2014)

10. R. W. Ayunin, W. D. Nugraha, G. Samudra, Jurnal Teknik Lingkungan, 5, 1-10 (2016)

11. R. Kumalasari, E. Zulaika, Jurnal Sains dan Seni, 5, 64-66 (2016)

12. F. P. Rahayu and E. Zulaika, Jurnal Sains dan Seni, 6 (2017)

13. B. Irawan, Metana, 10, 18-24 (2014)

14. R. Bulan, T. Mandang, W. Hermawan, Desrial. Jurnal Rona Teknik Pertanian, 9, 135146 (2016)

15. A. A. N. Supadma, D. M. Arthagama, Jurnal Bumi Lestari, 8, 113-121 (2008)

16. F. Firdaus, Kualitas pupuk kompos campuran kotoran ayam dan batang pisang menggunakan bioaktivator MOL tapai, Undergraduate Thesis, IPB University (2011)

17. U. Mayasari, B. S. Dewi, L. Afriani, S. P. Harianto, JITEK, 1, 1-13 (2018)

18. D. A. P. Ratna, G. Samudro, S. Sumiyati, Jurnal Teknik Mesin, 6, 1-5 (2017)

19. W. A. Akbari, Y. Fitriningsih, D. R. Jati, JITEK, 2, 1-10 (2015)

20. I. P. T. S. Adi, M. S. Yuliartini, I. G. B. Udayana, Sustainable Environment Agricultural Science, 4, 151-156 (2020)

21. N. Augustien, H. Suhardjono, Agritrop: Jurnal Ilmu-Ilmu Pertanian (Journal of Agricultural Science), 14, 54-58 (2016)

22. L. Liferdi, Jurnal Hortikultura, 20, 18-26 (2010)

23. N. Sumarni, R. Roslaini, R. S. Basuki, Y. Hilman, Jurnal Hortikultura, 22, 233-241 (2013)

24. K. H. Y. Uke, H. Barus, I. S. Madauna, E-Jurnal Agrotekbis, 3, 655-661 (2015)

25. E. S. Sutarta, Winarna, M. A. Yusuf, Jurnal Pertanian Tropik, 4, 84-94 (2017)

26. Sudrajat, A. Dawis, A. Wachjar, Indonesian Journal of Agronomy, 42, 222-227 (2014)

27. Sunarto, M. Ihsan, S. J. Rachmawatie, Agrodinamika, 12, 74-79 (2018)

28. A. Murtilaksono, T. Nurmala, A. Suriadikumah, Student e-Jurnal, 3, 1-11 (2014)

29. R. Prihatin, EKSAKTA: Berkah Ilmiah Bidang MIPA, 18, $62-68$ (2017)

30. W. Satriawi, E. W. Tini, A. Iqbal, Jurnal Penelitian Pertanian Terapan, 19, 115-120 (2019)

31. D. K. Anam, Jurnal Ilmiah Pertanian, 15, 31-36 (2019) 
32. Maswar, Kacang hias (Arachis pintoi) pada usahatani lahan kering (2004)

33. A. Fanindi, S. Yuhaeni, E. Sutedi, Oyo, Seminar Nasional Teknologi Peternakan dan Veteriner, 1, 701-706 (2009)

34. R. Anwar and Djatmiko, Jurnal Agroqua, 6, 152-158

35. R. K. Andri, Wawan, JOM Faperta, 4, 1-14 (2017)

36. D. Astutik, D. Suryaningdari, and U. Raranda, Jurnal Citra Widya Edukasi, 11, 67-76 (2019)

37. T. Koryati, Jurnal Penelitian Bidang Ilmu Pertanian, 2, 13-16 (2004)

38. B. Prasetya, S. Kurniawan, M. Febrianingsih, 2009, Jurnal Agritek, 17, 1022-1029 (2009) 